\title{
Business Strategy of Top Indian IT Company: MindTree
}

\author{
Madhushree $^{1}$, Revathi R. ${ }^{1}$, Anil Kumar ${ }^{2}$, \& P. S. Aithal ${ }^{2}$ \\ ${ }^{1}$ Research Scholar, Srinivas Institute of Management Studies, Srinivas University, \\ Mangalore - India \\ ${ }^{2}$ Srinivas Institute of Management Studies, Srinivas University, Mangalore - India \\ E-mail: madhushreemraju@gmail.com
}

Type of the Paper: Case Study.

Type of Review: Peer Reviewed.

Indexed In: OpenAIRE.

DOI: http://dx.doi.org/10.5281/zenodo.1249871.

Google Scholar Citation: $\underline{\text { IJCSBE}}$

How to Cite this Paper:

Madhushree., Revathi, R., Anil Kumar, \& Aithal, P. S. (2018). Business Strategy of Top Indian IT Company: MindTree. International Journal of Case Studies in Business, IT and Education (IJCSBE), 2(1), 22-36. DOI: http://dx.doi.org/10.5281/zenodo.1249871.

International Journal of Case Studies in Business, IT and Education (IJCSBE)

A Refereed International Journal of Srinivas University, India.

(C) With Authors.

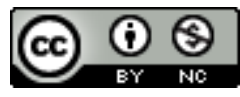

This work is licensed under a Creative Commons Attribution-Non Commercial 4.0 International License subject to proper citation to the publication source of the work.

Disclaimer: The scholarly papers as reviewed and published by the Srinivas Publications (S.P.), India are the views and opinions of their respective authors and are not the views or opinions of the S.P. The S.P. disclaims of any harm or loss caused due to the published content to any party. 


\title{
Business Strategy of Top Indian IT Company: MindTree
}

\author{
Madhushree $^{1}$, Revathi R. ${ }^{1}$, Anil Kumar ${ }^{2}$, \& P. S. Aithal ${ }^{2}$ \\ ${ }^{1}$ Research Scholar, Srinivas Institute of Management Studies, Srinivas University, \\ Mangalore - India \\ ${ }^{2}$ Srinivas Institute of Management Studies, Srinivas University, Mangalore - India \\ E-mail: madhushreemraju@gmail.com
}

\section{ABSTRACT}

MindTree is one of the fastest growing Information Technology companies in India. Founded in 1999, as an Indian IT company, MindTree has its presence across the world with a global workforce of approximately 16,000 employees. With a motivational slogan of "Welcome to Possible", MindTree serves various industries like Banking, Capital Markets, Manufacturing, Semiconductor, Retail, Media etc. MindTree Limited is an Indian multinational information technology firm having its head office in Bengaluru, India. Founded in 1999 the company employs roughly 16,500 IT professionals with annual revenue of \$780million. The MindTree has a goal to reach customers by giving proper services in right time. The company deals in e-commerce applications, mobile applications, cloud computing applications, digital transformation, data analytics, EAI, and ERP solutions, with more than 344 clients and 43 offices in over 17 countries, as on 31st March, 2017. It has its main operation in India and has major markets in United States and Europe. The company was started by ten IT professionals on 18 August 1999, who have previously worked for Cambridge Technology Partners, Lucent Technologies, and Wipro. In this paper, we have analysed the business strategy of MindTree by studying its operational level and business level strategies including operational strategy, services strategy, technology adoption strategy, HR strategies, financial strategies, marketing strategy, and new product development strategies. The paper also includes the company's innovation on sustainability through green strategy and corporate social responsibility strategy. Finally, based on SWOC analysis, some suggestions are given to speed up the sustainable growth.

Keywords: MindTree, Case study, Welcome to possible, Business strategy of IT Company.

\section{INTRODUCTION :}

MindTree founded in 1999 is an Indian IT company. MindTree has a global workforce of approximately 16,000 employees. It has the presence across the world \& K Natarajan is the present CEO of MindTree. MindTree serves various industries like Banking, Capital Markets, Manufacturing, Semiconductor, Retail, Media etc. MindTree provides a lot of IT related services like Application Development \& Maintenance, Application Services, Independent Testing, IT Consulting, Analytic, and infrastructure Management etc. MindTree is focusing mainly on technologies like Big Data, Mobility, and Cloud computing. It has acquired a number of companies off late 2010 in modern technology, for example, Magnet360 in the field of Sales force consulting and it also acquired Bluefin and Relational Solution in 2015 with the revenue of Rs 4689.6 Crores and the profit of Rs 603.3 Crores in the business. Mind Tree provides various R\&D facilities such as Bluetooth solutions, Digital Videos, Mind test, M-Watch, Atlas SAP - Systems, Applications, Products insurance and Omni Channel. MindTree's business is structured around clients in key verticals such as Banking, Capital Markets, Customer Devices and Electronics, Customer Filled Goods, Independent Software Merchants, Manufacturing, Insurance, Media and Entertainment, Retail, Semiconductors, and Travel and Hospitality industry. The company's bottomless proficiency in infrastructure and applications management converts Information Technology into a strategic asset. MindTree believes in developing concrete partnerships with client companies whether they need to run their business more efficiently or accelerate revenue growth. MindTree tries to foster a collegian 
environment in its business partnership where individual perspective is respected and honest dialogue is expected [1] [2].

Table 1: List of Top performed Indian IT Companies during 2017

\begin{tabular}{|c|c|c|c|c|}
\hline Rank & $\begin{array}{l}\text { Name of the } \\
\text { Company }\end{array}$ & $\begin{array}{l}\text { Year of } \\
\text { Establishment }\end{array}$ & Founder & Annual Revenue \\
\hline 01 & TCS & 1968 & $\begin{array}{l}\text { F. C. Kohli, } \\
\text { J. R. D. Tata }\end{array}$ & 17.57 billion $\$$ \\
\hline 02 & Infosys & 1981 & N. R. Narayana Murthy, & 2.241 billion $\$$ \\
\hline 03 & Wipro & 1981 & $\begin{array}{l}\text { Azim Premji, } \\
\text { M.H. Hasham Premji }\end{array}$ & 8.48 billion $\$$ \\
\hline 04 & $\begin{array}{l}\text { HCL } \\
\text { Technologies } \\
\end{array}$ & 1976 & $\begin{array}{l}\text { Mr. Shiv Nadar, Arjun } \\
\text { Malhotra }\end{array}$ & 7.4 billion $\$$ \\
\hline 05 & Tech Mahindra & 1986 & Anand Mahindra & 4.6 billion $\$$ \\
\hline 06 & L\&T Infotech & 1997 & $\begin{array}{l}\text { Henning Holck-Larsen } \\
\text { Soren Kristian Toubro. }\end{array}$ & 1 Billion \$ \\
\hline 07 & $\begin{array}{l}\text { Oracle Financial } \\
\text { Services }\end{array}$ & 1990 & Rajesh Hukku & Rs. 35.68 billion \\
\hline 08 & MindTree & 1999 & 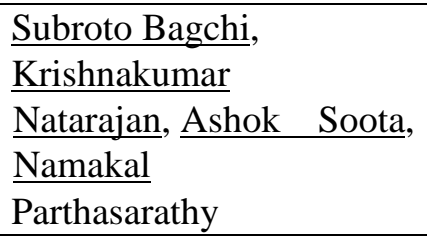 & 780 million $\$$ \\
\hline 09 & Mphasis & 2000 & $\begin{array}{ll}\text { Jerry } & \text { Rao } \\
\text { Jeroen Tas } & \\
\end{array}$ & $\begin{array}{lc}\text { Rs. } & 6,074 \quad \text { crore } \\
\text { (US } \$ 930 \text { million) }\end{array}$ \\
\hline 10 & Rolta India & 1989 & Kamal K. Singh & Rs. 3000 crore \\
\hline
\end{tabular}

\subsection{ABOUT COMPANY ANALYSIS AND ITS USE}

Company analysis is a kind of research method to understand the performance, opportunities, and challenges of a company by identifying various issues in internal and external environment and the decisions taken and to be taken to optimize the solution. It also involves unique features and critical comments on a chosen company and its business at the operational level, business level and corporate level [10], [19], [25]. Case study analysis is also used to study the advantages, benefits, constraints, and disadvantages of various products \& services, business models \& strategies, and various decisions taken by the managers at different levels, for various stakeholders in order to achieve the objectives of and sustainability of the company. Case study method of research is also used to prove many proposed theories and their postulates in social science and business management. In this paper, we have analysed the case of MindTree, the eighth ranked company in the list of Top performed Indian originated IT Companies during 2017 based on its annual revenue as shown in Table 1.

MindTree is trying to realize its business goal through developing optimum operational processes through suitable operational level strategies to control the cost by decreasing the wastage of resources and improving the operational efficiency. The MindTree aim is to give proper services to the customer and utilising resources properly by using strategies. In 2015-16, MindTree expanded their efforts by introducing an additional organic waste converter in Bangalore to treat food waste and also achieved 90\% wet waste conversion across Indian locations. MindTree thinks that a more effective solution in the future lies in focusing on generating less waste rather than increasing capacity for processing waste. Going forward, they would like their initiatives to focus more on the behavioural aspects of waste generation. MindTree's techno-social platform I Got garbage (IGG) has demonstrated how effectively wet waste can be transformed over and done with a natural process, without using electricity. IGG continues to address the issue of urban waste outside their premises while transforming the lives of waste pickers. Total waste generation, as well as per-capita waste generation came down by $3.20 \%$ and $13.68 \%$ respectively. 


\section{OBJECTIVES OF THE STUDY :}

This is a company case study paper based on the information collected from MindTree's business strategies in Information Technology industry sector. The paper deals with the following aim and objectives.

1. To learn the operation level and business level strategies of top Indian IT Company MindTree.

2. To know the growth saga of MindTree as a young IT company born recently and expanded globally at high speed.

3. To learn about MindTree strategy of facing the challenges using their innovative slogan "Welcome to possible".

4. To know about MindTree's strategies of exploring all possibilities as opportunities.

5. To use SWOC analysis for the recommendation of MindTree's future strategies for accelerated success.

6. To know about MindTree competitors and how they are competing with them for the further development.

\section{JOURNEY OF SUCCESS :}

- International digital trademark organisation (web, mobile and social) across 50 brands, 40 countries and 800 digital chattels for a leading CGP player.

- Transactions power automation, field intellect, and enhanced course scheduling solution for a global CGP player led to higher inventory turnover, upgraded profitability, and improved revenues.

- Applied an agent gateway solution to reduce operational costs and time to market of assurance products for a leading insurance major.

- Affected marketing solutions for product advancements over a mobile channel which resulted in improved consumer engagement for a leading credit card provider.

- Enabled one of the largest industrial tools suppliers to support more than 600,000 SKU's and 6,000 suppliers, on their e-commerce boards.

- Enlarged online sales for a leading car rental agency and saved USD 7 per reservation on digital channels.

- MindTree titled as 2016 Azure Novelty Partner of the Year by Microsoft [2], [3].

\section{EXPANDING CUSTOMERS THROUGH EXPLORING INDUSTRIES :}

MindTree's is focusing its energies towards making the company a significant global player by 2020 . The MindTree move is a big one, but it paid off very handsomely. The company today employs more than 16,000 people and annual revenues of over $\$ 600$ million. In the last 18 months or so, they accomplished the attention on the digital space, which refers to as "futuristic". Every industry will have an innovative idea to attract customer and expanding their business with giving more benefits will make clients to feel good on an individual product. Organisation actively involved in certifying the high quality of supremacy within the organisation. They absorbed on employing and fetching multiplicity to the MindTree board, in a highly appreciated group of self-governing directors. Their efforts and skills as a business leader have been recognised worldwide, winning several awards and tributes. They are spending time mentoring digital teams within the company and outside, and work on partnerships with the start-up ecosystem to solve unique customer problems. Another top priority will be mentoring future leaders in MindTree and creating a strong pipeline of talented leaders. Their actions and services as a specialized leader to have international documented charming numerous awards and a great compliment. An active member of the Manufacturer's Association for Information Technology and the Confederation of Indian Industry, their new role, will "help to drive aspirations and prepare the company for the future". Another top priority will be mentoring future leaders in MindTree and creating a strong pipeline of talented leaders. "MindTree is on a strong footing today to explore newer opportunities that will take us to a different orbit in the years ahead [3]. 


\section{MINDTREE INNOVATIVE SLOGAN: WELCOME TO POSSIBLE :}

MindTree broadcasted a new brand identity and logo, with the slogan "Welcome to possible" on September 28, 2012 by announcing its new logo and brand identity and calling it a crucial part of its journey towards 2020. According to its chairman Subroto Bagchi, as business and critical information systems transform, they understand that they required a company to expertise, which meant that their existing brand needed to be redefined. He also says that MindTree values over the past 14 years and they had people who were humble, down to earth and introspective but now it need people who are strategic, bold and decisive. The new logo essentially says that the firm sees a possibility where others see a full top. The company's new logo was designed by US based Siegel and Gale, which has designed brand logos for companies like Microsoft. The slogan says that "welcome to possible" means where they are ready for doing anything for improving the organisation as well as customer satisfaction whatever they are doing the main thing is to attract the customer by giving good services to them which will make an individual to feel good. Making anything is possible means that they should have positive energy that they can do anything for the customer satisfaction so only they modernized "welcome to possible". Making thing possible is not easy for everyone so whatever you are going to do or say that should be in positive that is MindTree's slogan to their customers by giving all possibilities [3].

\section{MINDTREE OPERATIONAL STRATEGY :}

MindTree project and operational strategies that determinate business growth and create new revenue streams. The MindTree approach reduces the risk of mid-course corrections and delivers more predictable outcomes. Operational strategy deals with the product design, Location, Layout, Process design, human resource and job design, Inventory, reliability and maintenance, quality management, schedule and procurement Expertise in complex technologies tool processes and advice created based on information and laboratory results from their global centers of excellence. Reduce security, operational and compliance exposures by correcting issues in the existing architecture slow down or prevent of non-compliant solutions proactively invest in solutions that support upcoming brand marketing needs, and decision facilitators for IT investments achieve operational excellence and improve governance and quality[4]. By developing operational strategies, a company can examine and implement effective and efficient systems for using resources, personnel and the work process. Service-oriented businesses also use straightforward operational strategies to link long-term and short-term commercial results and fashion an operational managing team for the superior results and they have to use corporate strategies contain sighted a company as a system of interrelated parts. Operational strategies should include customer-driven methodologies to meet the needs and requirements of a target market. By distinguishing core competencies, a company can develop courses such as client satisfaction, product expansion and assembling professional dealings with shareholders. The expansion of economical significances comes from the creation of a corporate strategy, market analysis, defining core procedures and showing needs examination. When developing a good service, a company should consider the wants of its customers, how it stands against the competition and how its technical measures relate to its customers' needs [5].

Table 2: Some Operational Level Strategies followed by Mindtree

\begin{tabular}{|c|c|c|}
\hline S. No. & Operational Strategies & Outcome \\
\hline 1. & Create new revenue streams. & To reduce costs \\
\hline 2. & $\begin{array}{l}\text { short- and long-term strategies based on } \\
\text { best practices }\end{array}$ & To deliver measurable results \\
\hline 3. & Decision facilitators for IT investments & $\begin{array}{l}\text { To increase both domestic and foreign } \\
\text { investment and to enhance their contribution } \\
\text { to national economic development. }\end{array}$ \\
\hline 4. & $\begin{array}{l}\text { Expertise in complex technologies tools } \\
\text { and processes. }\end{array}$ & To increase performance \\
\hline 5. & $\begin{array}{l}\text { Advice based knowledge and laboratory } \\
\text { results from global Centers of Excellence }\end{array}$ & $\begin{array}{l}\text { Decision making and Information transfer for } \\
\text { better result }\end{array}$ \\
\hline
\end{tabular}

Madhushree. et al. (2018); www.srinivaspublication.com 
6. Insight from in-depth field experience with customers across a wide range of To Increase customers and experienced industries

\subsection{MULTI-FIELD SERVICES STRATEGY THROUGH POSSIBLE}

MindTree supports automobile and distinct manufacturers to understand their strategic objectives by make unfluctuating production processes with customer demands that they enable collaboration with sellers for better returns. Increase speed in productivity and revenues through innovative solutions that improve the prominence of orders to reduce excessive inventory, increase sales force computerization and enable better reporting their knowledge of manufacturing in developing markets has led to in multi-dealer, multi-lingual and multi-branch system deployments. [6]. MindTree manages end-to-end data center production infrastructure for a large mobile telecommunications company spread across 180 countries. They have a track record of going 23 weeks without a P1 incident and they are still counting. They manage over 7000 servers with 100 gold applications, which directly impact the firm's financial turnarounds. Their determination has resulted in zero downtime for their billing system and online business, even during the peak season. This has resulted is absolute elimination of financial loss due to unavailability of IT estate [7] [8].

\subsection{MINDTREE TECHNOLOGY BUSINESS PARTNERSHIPS}

The following firms/consortiums are the major partners of MindTree Technologies:

(1) Microsoft gold certified partner: A Microsoft certified partner (MCP) is a strong that offers Microsoft-related goods and services, or maintenance for such. It is a part of the Microsoft Partner Network. They are established by Microsoft to be authorized, and they work effectually, and help customers with a collection of IT projects and specific products and services. While accredited to bring the employment to the same level as Microsoft gold specialized partner for the Understanding Services, and numerous MCPs offer livelihood as part of their service area.

(2) IBM premier business partner: IBM business partners have established the sales, connection, and support skills obligatory to cope within a progressively complex marketplace. IBM selects its business partners only who have specialized skills, and IBM wants to ensure that IBM business partners provide customers with the most skilled sales and technical support teams possible.

(3) Liferay partner: Liferay Entryway is a free and open source enterprise portal software creation. Distributed beneath the GNU, LGPL and not obligatory commercial license, Liferay was declared "Best Open Source Portal" by InfoWorld in 2007. It is principally used to power business intranets and extranets.

(4) Adobe implementation partner: Adobe Organisations combined is an American international workstation software business. The business is headquartered in San Jose, California, United States. Adobe has archaeologically concentrated upon the conception of programme and creativeness software products, with an additional new undertaking on the method to rich Internet application software development. It is best recognized for Photoshop, image excision software, Acrobat Reader, the Portable Document Format (PDF) and Adobe Creative Suite, as well as its beneficiary Adobe Creative Cloud.

(5) Oracle implementation partner: Oracle Organisation is software business which is established by an American multinational computer technology business, headquartered in Redwood Shores, California. The company concentrates mainly in evolving and advertising database software and technology, cloud engineer systems and enterprise software products mostly its own brands of database management systems. In 2015, Oracle remained the second-largest software by revenue, after Microsoft.

(6) SAP implementation partner: Systems, Applications \& Products (SAP) is a European multinational software corporation that graces enterprise software to accomplish business procedures and consumer relations. SAP is headquartered in Walldorf, Baden-Württemberg, Germany with provincial offices in 180 countries. The company has over 3, 35,000 customers in over 180 countries. (7) SDL Tridion consulting and implementation partner: SDL is international software and specialised company headquartered in Maidenhead, UK. SDL concentrates in; digital advertising software and services, organised content organization and language transformation software and 
services (including explanation services). SDL are recorded on the London Stock Exchange. SDL is an abbreviation for "Software and Documents Localization".

(8) Sitecore business partner: Sitecore is a customer experience organization that is responsible for web content management and multichannel marketing mechanisation software. The company was established in 2001 in Denmark.

(9) Kony implementation partner: Kony Inc, a cloud-based source of movement, Omni channel, and IT solutions, is located in Austin, Texas with 1200 workforce wide-reaching. Founded in 2007 the then Orlando-based business unrestricted its initial product, the KonyOne Stand in 2009. In 2012, Kony picked up Australian SAP look up company Sky Technologies.

(10) Netbiscuits implementation partner: Netbiscuits supports, publish, and monetize crossplatform mobile locations and apps. The netbiscuits cloud software display place assists the mobile internet services for online, media and sales companies such as e-Bay, Widespread Music, MTV Networks, HSN and Axel Springer, as well as most important interventions such as SapientNitro, Publicis, Razorfish, and Ogilvy. Globally netbiscuits progressions are more than 8 billion mobile page carriages for its consumers each month. Started in 2000, the company has over 100 workforces in the USA, Germany, UK, Singapore, and Australia [9] [10].

\subsection{EXPLORING NEW POSSIBILITIES}

MindTree reported revenue growth of 2.5\% q-o-q for the quarter ending 2017. The quarter observed multi-year and the multi- million wins with a leading global brand. A strong contract of pipeline, improved customer metrics, recognized leadership, global right-sourcing distribution model, and capability to attract and maintain talent key success factors driving our confidence for a promising future. During these years, MindTree eyes strong presence in 20 global cities by concerning their strategy to carry on globalizing and developing expertise. Focus on Omni-Channel and Analytics Solutions created to drive consumer engagement and commerce, Integrated Insights and OmniChannel Service Instrumentation [11]. Omni-Channel Service Transposition enables retailers to provide enhanced customer experiences by creating synergy across multiple channels during the shopping process. Integrated Customer Insights enables retailers to create a context-based consumer personality. Analytics plays a significant role in maximizing potential of human capital. In the IT industry, where human capital is the most crucial factor in impacting on cost and analytics play a significant role. Turnover modelling and risk management of high-profile candidates are a few of the emerging areas where the insights can significantly help manage talent [12] [13]. MindTree wants to revolutionize waste management through 'I Got Garbage'. It's MindTree's ambitious project that aims to use technology to change waste management helping to create a better, cleaner community. The project looks at waste from a new perspective, one beneficial to the people working in waste management. The making new possibilities that whatever they feel its goods that they will do with exploring the new possibilities that how they can make an innovative creation of doing or exploring new possibilities. Any organisation should feel that without making any unwanted things how they can implement the new things which will make an organisations to feel good with happy of giving benefits to all who are all working for the organisation with taking all about projects and doing new things and welcoming an advanced prospects to the organisation [14] [15] [16].

\subsection{HR HIRING \& TRAINING STRATEGY}

\section{HR Hiring: Recruitment process conducts by MindTree consists for following stages:}

1. Written exam

2. Group Discussion

3. Technical Interview

4. HR Interview

Training Strategy

MindTree Concentration drive not only becomes a practice in their technology field but also one or more of the IGs. Training and Development practices are designed for planned and recognised instructions and to provide adequate 'knowledge' to extended enterprise to meet the expectations of customers this arrangement not only brings their clients with a distinct advantage but also helps people! Their training is designed to:

- Support MindTree Minds in constantly upgrading their skills.

- Support MindTree Minds in their present role and formulates them for their next role. 
- Ensures that everyone in delivery is skilled to perform at the level their role requires.

- Exposes MindTree Minds to the best practices in the industry.

Training

Helps build an effective supporting network of colleagues and mentors [17].

1. New product/ release information

2. Pricing plans

3. How-to-tips

4. Compliance training

5. Soft-skills training

Internal communications

1. Marketing campaigns

2. Incentive plans

3. Policy updates

\subsection{STRATEGIC PILLARS DESIGNED FOR EXPANSION}

The strategic pillars designed for organizational transformation consists of digital transformation, delivery transformation, Sales transformation and people focus as shown in Figure 1.

\section{Digtal Transformation}

1. Proactive offering led deals

2. key partnership and alliance

3. Wide and deep technology

4. A strong base of "Digitally enabled".

\section{Delivery Transformation}

1. Drive productivity focus

2. Deepening customer enagement

3. Increased usage of automation

\section{Sales Transformation}

1. Proactive sales training and kits

2. Enhancing brand reputation

3. Accounting based co-ordinated sales and marketing.

\section{Mindtree \\ Strategy}

\section{People focus}

1. Mindtree culture

2. Best place to work

3. Innovation and Intrapreneurship

Fig. 1: MindTree’s strategic pillars

\subsection{FINANCIALS}

1.1.1 A comparative summary of MindTree Ltd.'s Financials for last two years 2016 \& 2017 is given in table 3 .

Table 3: Last two years Financial Statement [2]

\begin{tabular}{|l|l|l|l|}
\hline Parameter & $\begin{array}{l}\text { MAR'17 } \\
(\mathrm{Cr} .)\end{array}$ & $\begin{array}{l}\text { MAR'16 } \\
(\mathrm{Cr} .)\end{array}$ & $\begin{array}{l}\text { YoY } \\
\text { \%Change }\end{array}$ \\
\hline EQUITY AND LIABILITIES & & & \\
\hline Share Capital & 168.00 & 167.80 & $0.12 \%$ \\
\hline Share Warrants \& Out standings & & & \\
\hline Total Reserves & $2,584.70$ & $2,285.60$ & $13.09 \%$ \\
\hline Shareholder's Funds & $2,757.80$ & $2,464.10$ & $11.92 \%$ \\
\hline Long-Term Borrowings & $\mathbf{0 . 0 0}$ & $\mathbf{0 . 0 0}$ & $\mathbf{0 . 0 0 \%}$ \\
\hline Secured Loans & 0.00 & 0.00 & $0.00 \%$ \\
\hline
\end{tabular}

Madhushree. et al. (2018); www.srinivaspublication.com 
International Journal of Case Studies in Business, IT and Education (IJCSBE), ISSN: 2581-6942, Vol. 2, No. 1, May 2018.

\begin{tabular}{|c|c|c|c|}
\hline Unsecured Loans & 1.30 & 1.80 & $-27.78 \%$ \\
\hline Deferred Tax Assets / Liabilities & -84.00 & -73.40 & $14.44 \%$ \\
\hline Other Long Term Liabilities & 26.60 & 83.90 & $-68.30 \%$ \\
\hline Long Term Trade Payables & 0.00 & 0.00 & $0.00 \%$ \\
\hline Long Term Provisions & 0.00 & 0.00 & $0.00 \%$ \\
\hline Total Non-Current Liabilities & -56.10 & 12.30 & $-556.10 \%$ \\
\hline \multicolumn{4}{|l|}{ Current Liabilities } \\
\hline Trade Payables & 132.60 & 143.20 & $-7.40 \%$ \\
\hline Other Current Liabilities & 335.60 & 350.10 & $-4.14 \%$ \\
\hline Short Term Borrowings & 94.20 & 40.00 & $135.50 \%$ \\
\hline Short Term Provisions & 131.30 & 154.60 & $-15.07 \%$ \\
\hline Total Current Liabilities & 693.70 & 687.90 & $0.84 \%$ \\
\hline Total Liabilities & $3,395.40$ & $3,164.30$ & $7.30 \%$ \\
\hline \multicolumn{4}{|l|}{ ASSETS } \\
\hline Non-Current Assets & 0.00 & 0.00 & $0.00 \%$ \\
\hline Gross Block & $1,084.60$ & $1,005.90$ & $7.82 \%$ \\
\hline Less: Accumulated Depreciation & 704.20 & 585.80 & $20.21 \%$ \\
\hline Less: Impairment of Assets & 0.00 & 0.00 & $0.00 \%$ \\
\hline Net Block & 380.40 & 420.10 & $-9.45 \%$ \\
\hline Lease Adjustment $\mathrm{A} / \mathrm{c}$ & 0.00 & 0.00 & $0.00 \%$ \\
\hline Capital Work in Progress & 19.20 & 23.20 & $-17.24 \%$ \\
\hline Intangible assets under development & 0.00 & 0.00 & $0.00 \%$ \\
\hline Pre-operative Expenses pending & 0.00 & 0.00 & $0.00 \%$ \\
\hline Assets in transit & 0.00 & 0.00 & $0.00 \%$ \\
\hline Non-Current Investments & 866.60 & 858.60 & $0.93 \%$ \\
\hline Long Term Loans \& Advances & 199.30 & 180.80 & $10.23 \%$ \\
\hline Other Non-Current Assets & 16.90 & 32.40 & $-47.84 \%$ \\
\hline Total Non-Current Assets & $1,482.40$ & $1,515.10$ & $-2.16 \%$ \\
\hline \multicolumn{4}{|l|}{ Current Assets Loans \& Advances } \\
\hline Currents Investments & 586.90 & 226.60 & $159.00 \%$ \\
\hline Inventories & 0.00 & 0.00 & $0.00 \%$ \\
\hline Sundry Debtors & 806.10 & 882.50 & $-8.66 \%$ \\
\hline Cash and Bank & 225.00 & 192.40 & $16.94 \%$ \\
\hline Other Current Assets & 89.40 & 94.10 & $-4.99 \%$ \\
\hline Short Term Loans and Advances & 205.60 & 253.60 & $-18.93 \%$ \\
\hline Total Current Assets & $1,913.00$ & $1,649.20$ & $16.00 \%$ \\
\hline Net Current Assets (Including Current Investments) & $1,219.30$ & 961.30 & $26.84 \%$ \\
\hline Total Current Assets Excluding Current Investments & $1,326.10$ & $1,422.60$ & $-6.78 \%$ \\
\hline Miscellaneous Expenses not written off & 0.00 & 0.00 & $0.00 \%$ \\
\hline Total Assets & $3,395.40$ & $3,164.30$ & $7.30 \%$ \\
\hline Contingent Liabilities & 72.00 & 72.00 & $0.00 \%$ \\
\hline Total Debt & 96.00 & 42.30 & $126.95 \%$ \\
\hline Book Value (in Rs.) & 163.85 & 146.21 & $12.07 \%$ \\
\hline Adjusted Book Value (in Rs.) & 163.85 & 146.21 & $12.07 \%$ \\
\hline
\end{tabular}

\section{BUSINESS LEVEL STRATEGIES OF MINDTREE :}

Organization's basic objective should be concentrating on client needs, preferences and satisfaction in order to achieve normal returns. This is completed through Business-level strategies. Business level strategies detail actions taken to provide value to customers and gain a competitive advantage by exploiting core competencies in specific, individual product or service markets. Business-level 
strategy is concerned with a firm's position in an industry, relative to competitors and to the five forces of competition. Knowing ones customer is very important in obtaining and sustaining a competitive advantage (Table 4). Being able to successfully predict and satisfy future customer needs is important [18] [19].

Table 4: Some Business level strategies followed by MindTree

\begin{tabular}{|r|l|l|}
\hline $\begin{array}{l}\text { S. } \\
\text { No. }\end{array}$ & Operational Strategies & Outcome \\
\hline 1. & Digital business strategy & To transform your business by leveraging digital technologies \\
\hline 2. & $\begin{array}{l}\text { Consider Cross-Industry } \\
\text { Best Practices }\end{array}$ & Easy availability of leverage \\
\hline 3. & $\begin{array}{l}\text { Analyze and Leverage } \\
\text { Partner Capabilities }\end{array}$ & Choosy in partners and increase profitability \\
\hline 4. & Ignite software design & Quick and easy movement in software development. \\
\hline 5. & $\begin{array}{l}\text { Application and of the } \\
\text { development } \\
\text { automation }\end{array}$ & $\begin{array}{l}\text { Eliminating time barrier and maximize the benefits of the } \\
\text { application and automation will integrate the challenges of the } \\
\text { support system. }\end{array}$ \\
\hline
\end{tabular}

\section{SUSTAINABILITY THROUGH GREEN STRATEGY :}

The MindTree approach to commercial sustainability is drawn from their mission: "MindTree engineer meaningful technology solutions to help business and society's decoration". For them, sustainability is a business imperative, which aims to create and maintain the necessary circumstances under which individuals, the planet and their profits exist in productive consistency. This framework enables them to adopt an expanded variety of values that will main way to measure proper traditional economic parameters along with environmental and social success. MindTree's realistic approach to sustainability is built on the principles, processes, practices, and services of the triple bottom line: people, the planet, and profit [20] [21].

\subsection{THE FRAMEWORK IS BUILT BASED ON THREE PILLARS}

(1) Ecological sustainability:

It is one of the most important pillars of MindTree's sustainability structure. With the growing significance of concerns such as weather modification, energy advance and water stress, they distinguish conservational risks and the reputation of handling influence on the atmosphere. They aim to minimize the conservational impact of business processes through resource preservation performs, GHG track decline, effectual energy controlling, water competency, maintainable waste management and by appealing MindTree Minds as evangelists.

\section{(2) Governance and advocacy:}

MindTree's beliefs are very goods of the enterprise and have been incorporated into every system and process. They conduct themselves with the highest ethics of reliability and are crystal clear in professional connections and dealings that may influence the place of work. They meet the terms with all appropriate: local, national and international rules, regulations, codes of practice, directives and conduct business operations with honesty and integrity.

(3) Workplace sustainability:

MindTree has assurance in unbiased environments that raise its stakeholder's spirits equivalent commitment placed into practice, health, wellbeing, diversity and inclusion. With a work-related health and safety organization in place they raise stakeholder's spirits and keep a safe work environment provided that fair working conditions to all MindTree minds. The MindTree is acquainted with the social concern is an essential part of its corporate social principles. They committed to support and nurture societies through pioneering explanations to satisfy progressing needs of the society [22].

\subsection{CORPORATE SOCIAL RESPONSIBILITY(CSR) ACTIVITIES THROUGH MINDTREE FOUNDATION}


MindTree's CSR creativities are mainly concentrated to benefit public with disabilities (PWD), encourage education, and create supportable employment prospects. They are full of superiority that MindTree outreach programs compressed about 32,000 people in 2016-17. This year maxim the Foundation involved in over the 20 creativity in association with 17 NGOs and the banquet across five states. They generated a healthy evaluation process called H-E-A-T (Hunger - Enforcement Awareness - Transformation) for an assortment of NGOs/assignment valuation, project delivery and intensive care as channelled by the Company Act 2013, CSR Rules Sec 135.They also technologically advanced CSR effectiveness Index that allowed factoring in qualitative procedures into their project estimation, which is highly significant while measuring CSR projects of intangible nature [23] [24]. The total contribution of MindTree for CSR activities through MindTree Foundation and the total beneficiaries are shown in table 5 .

Table 5: CSR Activities by MindTree [2]

\begin{tabular}{|l|l|l|}
\hline Sl. no. & CSR Activities & INR \\
\hline 01 & Total CSR spend by MindTree & $109,065,812$ \\
\hline 02 & Total fund allotted to MindTree Foundation & $53,942,810$ \\
\hline 03 & Total fund spent by MindTree Foundation & $40,344,144$ \\
\hline 04 & Total beneficiaries & 58,930 \\
\hline 05 & CSR beneficiaries & 32,117 \\
\hline 06 & Volunteering beneficiaries & 26,813 \\
\hline 07 & Volunteers involved & 8,819 \\
\hline
\end{tabular}

\section{SWOC ANALYSIS :}

SWOC analysis and ABCD analysis are used to study a company's internal capabilities [26], [27], [28], [29]. The SWOC Analysis of MindTree focuses on Strengths, Weakness, Opportunities, and Challenges of a company's businesses and operations. In profile shows an inclusive view of the company's main is strength and weakness and the potential opportunities and threats. MindTree Ltd. is an India-based software development company. The company offers IT Services, infrastructure management, and technical support, independent testing, knowledge services and product engineering comprising $R \& D$ services, software product engineering, and wireless products. MindTree provides its services to various industries such as retail, manufacturing, insurance, automotive, medical electronics, industrial structures, storage and computing systems, capital markets, and communication systems.

1.2

1.3 SWOC - Strengths

(1) Domestic market: It is an internal market or domestic transaction, is the source where the demand for goods and services are more with having securities within a single country. In domestic trading, a firm faces only one set of competitive, economic, and market issues and essentially must deal only with one set of customers, although the company may have several segments in a market.

(2) High profitability and revenue: An income is what is left of the revenue a business makes after it pays all expenses directly related to the generation of the returns, such as producing a product, and other expenses related to the conduct of the business activities.

(3) Experienced business units: A logical element or segment of a company (such as accounting, production, marketing) representing a specific business function, and a definite place on the organizational chart, under the domain of a manager. This is also called department, division, or a functional area.

(4) Existing distribution and sales networks: A distribution channel is the network of individuals and organizations involved in getting a product or service from the producer to the customer. Distribution channels are also known as marketing channels or marketing distribution channels.

(5) Industry has unique products: Unique Selling Proposition (USP) Entrepreneur Staff. The purpose or concern presented by a seller as the reason that only one product or service is different 
from better than other competitors. In advance, one can begin to trade your product or service to anyone else whom you are feeling to sell it.

(6) High industry growth rates: The industry has proper sales growth where it can be identified by sales identified within a given consumer group over a specified time frame. When the administration of a business looks at the success of the product, it needs to deduct the overall market growth rate from the observed product sales growth.

SWOC - Weaknesses

(1) High investments in research and development: Companies should invest in research and development (R\&D) to create new and innovative products and add features to old products. $\mathrm{R} \& \mathrm{D}$ refers to the part of a company's business plan that seeks to gain knowledge to develop, design and enhance that company's products, services, technologies or processes.

(2) Future productivity: The story behind global GDP growth over the decades can be broken down into two pieces: growth from an increase in the number of employed persons and growth from labour productivity, which shows an increase in the average productivity of employed people.

1.4

\subsection{SWOC - Opportunities}

(1) Global markets: The activity of buying or selling goods and services will take places in all over the countries of the world and the value of the goods and services has taken place.

(2) New market trends can be seen: The buyer will be having more efforts to identify market trends by using a technical analysis of a framework which describes market trends as expectable price tendencies within the market when price reaches to support and resistance level, varying over time.

(3) Global growth opportunities: In a perfectly integrated world economy, capital should be invested where it expects to earn thehighest risk-adjusted return. Much of the research on actual variables and capacities is strongly balances with the belief of global integration.

(4) New trade agreements between countries are possible: Multilateral trade agreements are commerce treaties between three or more nations. The agreements reduce tariffs and make it easier for businesses to import and export. Since they are among many countries, they are difficult to negotiate.

(5) Market changes fast: The expression "fast-expanding market" refers to any rapidly developing opportunity. The market is the central point, and it may occur at supranational, national, regional, industry, cluster, and firm or even product level.

(6) Industry shows positive trend: Industry will have positive trend to predict future by having proper aspect like technical analysis where it can helps in stock improvement. Trend only one thing that to know about future and how to work better with having the positive trend.

1.6

1.7 SWOC - Challenges

(1) Technological problems: Design implies change and improvement, solving technical problems and meeting new needs. It is open to identify an individual meets regularly to discuss operational and near-term technical problems of the Internet.

(2) Increasing costs: The increasing in cost is a significant attention for business proprietors, who struggle to have their operations running at full volume so as to complete the highest level of profit, is possible. In this situation, increasing production means higher production costs due to basic production. This explains the law of increasing costs.

(3) Government regulations: Government kept some rules and regulation where it's can be followed by every individual organisation for giving protection to employees and also for protecting the environment.

(4) Financial capacity: Financial capacity can be defined as "available organizational resources and relationships (both external and internal) that enable organizations to pursue their mission and fulfil their roles”.

(5) Economic barriers can be seen: Barriers to entry with having more difficulties to enter in a given market. These difficulties may include government regulation and patents, technology challenges, start-up costs, or education and licensing requirements. Let's discuss a few of the most common barriers. 
(6) Price charges are possible: One of the main confidences for business success is pricing products properly. Price your products correctly and that can enhance how much you sell, creating the foundation for a business that will prosper. Get your pricing strategy where it will give an idea and you may also fall problems that your business may never be able to overcome [25] [26] [27].

\section{SUGGESTIONS FOR FURTHER IMPROVEMENT :}

Based on the above analysis we suggest following recommendations for further sustainable improvement:

1. Even though Research and Development is one of the most important factors for the business development but MindTree invests too much on Research \& Development other than investments in the business, expansion, leverages and debt or mortgages.

2. MindTree has to control the cost by decreasing the wastage of resources and improving the operational efficiency.

3. MindTree should focus on more innovative ideas to attract customer and expanding its business by giving more benefits will ensure clients to feel good about any product.

4. MindTree has to develop an operational strategy, where the company can examine and implement effective and efficient systems for using resources, personnel and the work process.

5. The company should include customer-driven methodologies to meet the needs and requirements of a target market by distinguishing core competencies. A company can develop courses such as client satisfaction, product expansion and assembling professional dealings with shareholders.

6. It can increase the productivity by two ways in terms of an increase in the number of employed persons and growth from labour productivity with the increase of average productivity of the employees.

\section{CONCLUSION :}

In this paper, we have discussed the business strategies, innovative ideas, operational strategies adopted, and the importance of research in case of MindTree IT company to achieve its objectives. The advantages and benefits of these business processes and strategies used in the organisation to differentiate their performance are also studied. MindTree provides technology transformation and execution services. MindTree Infrastructure Management Services offers outsourcing of data center infrastructure management, end user computing services, application support, and technical support. MindTree also offers proprietary management software, MWatch, which is integrated and used along with a customer's existing tool set. The analysis provided in-depth information about the business strategies of MindTree and how these strategies impacted on its organisational development.

\section{REFERENCES}

[1] Satyendra C. Pandey, Andrew Dutta, (2014). Knowledge management helps MindTree to flourish: Company makes the most of employee creativity. Human Resource Management International Digest, 22(4), 19-21. DOI: https://doi.org/10.1108/HRMID-07-2014-0082.

[2] https://www.mindtree.com, Retrieved- on 10/01/2018.

[3] Madhavi, R., \& Ramnath, N. G. (2007). Contribution of MindTree consulting limited to Indian IT industry and study of its future challenges and prospects. http://research.iimb.ernet.in/handle/123456789/4156.

[4] Keerthan Raj, (2017). Indigenous Management Practices- A Case Study on Street Vendors. International Journal of Case Studies in Business, IT and Education (IJCSBE), 1(2), 29-36. DOI: http://dx.doi.org/10.5281/zenodo.914458.

[5] Aithal, P. S. (2016). The concept of Ideal Strategy \& its realization using White Ocean Mixed Strategy. International Journal of Management Sciences and Business Research (IJMSBR), 5(4), 171-179. DOI: http://doi.org/10.5281/zenodo.161108.

[6] Michael E. Porter, (1997).COMPETITIVE STRATEGY, Measuring Business Excellence, 1(2), 12-17, DOI:https://doi.org/10.1108/eb025476. 
[7] Aithal, P. S. (2016). Review on Various Ideal System Models Used to Improve the Characteristics of Practical Systems. International Journal of Applied and Advanced Scientific Research, 1(1), 47-56. DOI :http://doi.org/10.5281/zenodo.159749.

[8] Aithal, P. S. \& Acharya, R. K. (2016). Strategic Management Models \& Indian Epics, International Journal of Management Sciences and Business Research (IJMSBR), 5(4), 180-188. DOI: http://doi.org/10.5281/zenodo.161093.

[9] Dulababu, T. (2017). Case Study: A Diagnostic Study on Fundamentals of Top Indian IT Companies. Advances in Management, 10(3), 8-20.

[10] Aithal, P. S., (2017). Company Analysis - The Beginning Step for Scholarly Research. International Journal of Case Studies in Business, IT and Education (IJCSBE), 1(1), 1-18. DOI: http://dx.doi.org/10.5281/zenodo.573769.

[11] London, T., \& Hart, S. L. (2004). Reinventing strategies for emerging markets: beyond the transnational model. Journal of international business studies, 35(5), 347-360. DOI: http://www.palgrave-journals.com/jibs/journal/v35/n5/pdf/8400099a.

[12] Aithal, P. S. (2015). Mobile Business as an Optimum Model for Ideal Business. International Journal of Management, IT and Engineering (IJMIE), 5(7), 146-159. DOI: http://doi.org/10.5281/zenodo.163880.

[13] Aithal, P. S. (2016). A Review on various E-business and M-business models \& Research Opportunities, International Journal of Management, IT and Engineering (IJMIE). 6(1), 275298. DOI: http://doi.org/10.5281/zenodo.161146.

[14] Sharma, M., \& Gupta, P. (2015). Factor analysis performance evaluation of listed companies in Indian IT industry. International Journal of Business Performance Management, 16(4), 45747.DOI:https://www.inderscienceonline.com/doi/abs/10.1504/IJBPM.2015.072244.

[15] Aithal, P. S., (2015). Concept of Ideal Business \& Its Realization Using E-Business Model. International Journal of Science and Research (IJSR), 4(3), 1267-1274. DOI: http://doi.org/10.5281/zenodo.61648.

[16] Weihrich, H. (1982). The TOWS Matrix a Tool for Situational Analysis. Long Range Planning, 15(2), 54-66. DOI: https://doi.org/10.1016/0024-6301(82)90120-0.

[17] Chandhana, K., \& Easow, D. T. (2015). Performance Appraisal Method Used in Top 10 IT Companies-360 Degree Feedback \&Balanced Score Card: A Review. Bonfring International Journal of Industrial Engineering and Management Science, 5(2), 73-76.

[18] Weihrich, H. (1982). The TOWS matrix-A tool for situational analysis. Long range planning, 15(2), 54-66.

[19] Aithal, P. S. (2017). An Effective Method of Developing Business Case Studies Based on Company Analysis. International Journal of Engineering Research and Modern Education (IJERME), 2(1), 16-27. DOI: http://dx.doi.org/10.5281/ZENODO.400579.

[20] Kohn, C. Huge-Brodin, M., (2008). Centralised distribution systems and the environment: how increased transport work can decrease the environmental impact of logistics. International Journal of Logistics: Research and Applications, 11(3), 229-245.

[21] Aithal P. S. (2017). Impact of Domestic, Foreign, and Global Environments on International Business Decisions of Multinational Firms: A Systematic Study. International Journal of Management, Technology, and Social Sciences (IJMTS), 2(2), 57-73. DOI:http://dx.doi.org/10.5281/zenodo.1067103.

[22] Aithal P. S. (2017). A critical study on Various Frameworks used to analyze International Business and its Environment. International Journal of Applied Engineering and Management Letters(IJAEML), 1(2), 74-98. DOI: http://dx.doi.org/10.5281/zenodo.1053578. 
[23] Heal, Geoffrey M. (2004). Corporate Social Responsibility - an Economic and Financial Framework. pp. 1-33. DOI: http://dx.doi.org/10.2139/ssrn.642762.

[24] Thomas Andre., (2014). Corporate Social Responsibility Boosts Value Creation at the Base of the Pyramid. Cahier de recherché,11, 10-20.https://hal.archives-ouvertes.fr/hal-00989791.

[25] Aithal, P. S. (2017). Industry Analysis - The First Step in Business Management Scholarly Research. International Journal of Case Studies in Business, IT and Education (IJCSBE), 2(1), 1-13. DOI: http://dx.doi.org/10.5281/zenodo.810347.

[26] Aithal, P. S., (2017). ABCD Analysis as Research Methodology in Company Case Studies. International Journal of Management, Technology, and Social Sciences (IJMTS), 2(2), 40-54. DOI: http://dx.doi.org/10.5281/zenodo.891621.

[27] Aithal, P. S. and Suresh Kumar, P. M. (2015). Applying SWOC Analysis to an Institution of Higher Education. International Journal of Management, IT and Engineering (IJMIE), 5(7), 231-247. DOI :http://doi.org/10.5281/zenodo.163425.

[28] Aithal, P. S., (2016). Study on ABCD Analysis Technique for Business Models, Business Strategies, Operating Concepts \& Business Systems. International Journal in Management and Social Science, 4(1), 98-115. DOI :http://doi.org/10.5281/zenodo.161137.

[29] Aithal, P. S., Suresh Kumar P. M. (2017). Ideal Analysis for Decision Making in Critical Situations through Six Thinking Hats Method. International Journal of Applied Engineering and Management Letters (IJAEML), 1(2), 1-9. DOI:http://dx.doi.org/10.5281/zenodo.838378. 